\title{
NEWCASTLE DISEASE ANTIBODY TITRE IS DEPENDENT ON SERUM CALCIUM CONCENTRATION
}

\author{
Jasminka BožıČKOVIĆ ${ }^{1}$, P. BoŽIČKOVIĆ ${ }^{1}$, Gabrijela KRIVEC ${ }^{1}$, W. L. RAGLAND ${ }^{2,3}$ \\ Estella PRUKNER-RADOVČIĆ ${ }^{2}$ and H. MAZIJA ${ }^{2 *}$ \\ ${ }^{1}$ Poultry Centre, Croatian Veterinary Institute, Heinzelova 55, 10000 Zagreb, Croatia; \\ ${ }^{2}$ Department of Poultry Diseases, Veterinary Faculty, Heinzelova 55, 10000 Zagreb, \\ Croatia, and ${ }^{3}$ Department of Avian Medicine, University of Georgia, Athens, Georgia \\ 30602-4875, USA
}

(Received February 15, 1999; accepted May 10, 1999)

Chickens were fed diets having optimal, high, and low levels of calcium for 42 days. Serum samples were collected at 14, 28 and 42 days of age, and serum calcium and haemagglutination inhibition titres for Newcastle disease virus were measured. The chickens were vaccinated at 14 days for Newcastle disease. Antibody titres were significantly increased by high dietary calcium and depressed by low dietary calcium. Mean titre was $2.5\left(\log _{2}\right)$ for the optimal diet, 3.2 for the high-calcium diet, and 1.6 for the low-calcium diet. Antibody titres were dependent on serum calcium concentration $\left(\mathrm{r}^{2}=0.98\right.$ at 14 days, 0.99 at 28 days, and 0.78 at 42 days).

Key words: Newcastle disease virus, antibody titre, chicken, serum calcium, dietary calcium

Calcium is an essential mineral involved in a wide range of physiological functions essential for health. It has also been associated with, and implicated in, the pathogenesis of several diseases. The ubiquity of calcium in the extracellular and intracellular milieu complicates discernment of its relationships to specific physiological events and their aberrant behaviour. Nevertheless, essential roles for calcium have been elucidated, and its involvement in bone formation, neural impulses, and muscle contraction has been known for many decades. Although still controversial, an inverse relationship with hypertension has gained wid espread acceptance (Birkett, 1998; McCarron, 1998).

Calcium has been identified as a major participant in signal transduction for many cellular functions, among them those appertaining to immunity. Its i nvolvement in immunity has followed two avenues of investigation, mostly at molecular levels, but also at the dietary level. The stage is set for convergence of the importance of nutritional calcium, its assimilation and distribution, on i m-

*Corresponding author. E-mail: hmazija@vef.hr; Fax: 385-1-239-0280 
mune responses in the intact animal with elucidation of the responsible mech anisms at the molecular levels.

In commercial production of poultry, nutritional concerns have focused primarily on optimal levels of calcium for adequate bone structure and pala tability of feed. High levels of calcium in feed result in stronger bone, but feed conversions may suffer, resulting in lower profitability. Consequently, calcium level in poultry feed has been established without considering the effects on other physiological functions, namely immune competence, that also affect commercial profitability.

The importance of dietary calcium and the effects of vitamin D on its avai 1ability for immune function have become better appreciated in the last few years, both for poultry and mammals, including humans. We reported in 1994 that male chickens fed $1.3 \%$ calcium, the upper limit for palatability, had significantly better immune responses to Newcastle disease vaccine than chickens fed $0.65 \%$ calcium, the lower limit recommended for chickens (Ragland et al., 1994). Low levels of lead also increased vaccine responses, and the effect of both metals was additive. The favourable effect of calcium on antibody responses to Newcastle disease va ccination was confirmed in chickens fed $1.2 \%$ calcium (Bakalli et al., 1996). In contrast to chickens, Garlich et al. (1992) reported that low dietary calcium resulted in improved antibody responses to sheep red blood cells ( SRBC) as well as enhanced cell-mediated responses by tu rkeys.

Aslam et al. (1998) reported that female chickens made hypocalcaemic by feeding a diet deficient in vitamin $\mathrm{D}$ had impaired cellular immune responses but normal humoral responses to SRBC, a T-dependent antibody response. They did not examine response to Newcastle disease virus, a T-independent antibody $\mathrm{r}$ esponse. Suppressive effects of hypovitaminosis D on immunity have been o bserved also in mice (Yang et al., 1993). Treatment with the vitamin D analogue, MC 1288, a candidate drug for prevention of graft rejection, caused immune suppression in rats (Johnsson et al., 1996).

Influence of dietary calcium on immune responses has been observed in other species. Calcium-deficient diets were immunosuppressive for rats whereas calciumenriched diets were stimulatory ( Sukhanov et al., 1995). Long-term consumption of yoghurt resulted in increased levels of serum ionized calcium and concomitantly increased production of interferon-gamma by $\mathrm{T}$ cells isolated from subjects on the yoghurt diet (Halpern et al., 1991). Koval (1997) measured trace elements in hair from patients with ischaemic heart disease as a reflection of dietary and environmental exposure to these minerals over a prolonged period of time. Serum immunoglobulin levels, phagocytosis by neutrophils, and lymphocytes, helper cells, NK cells and $\mathrm{T}$ cell receptors were measured and correlated with mineral levels. Three elements correlated strongly with the immunologic measurements; $\mathrm{Pb}>\mathrm{Ca}>\mathrm{Zn}(\mathrm{p} \leq 0.05)$. The patients were not immunosuppressed which was attributed to normal levels of $\mathrm{Ni}, \mathrm{Mo}$ and $\mathrm{Si}$. 


\section{Materials and methods}

Experimental design. One hundred and fifty newly hatched chickens were randomly assigned to three treatment groups and fed either low, optimal, or high levels of calcium diets. Serum samples for calcium and antibody titres were co 1lected from 20 chicks at hatch before feed was provided. Twenty chickens were removed from each group at Day 14, weighed, and serum samples collected for calcium and antibody assays. The remaining chickens were vaccinated oculonasally with live LaSota Newcastle disease vaccine (Pestikal ${ }^{\circledR}$, Pliva d.d., Zagreb, Croatia). Ten birds were removed from each group at 28 days, weighed, and s erum samples collected. At 42 days of age the remaining 20 birds in each group were weighed and serum samples co llected.

Animals. Hybrid female chickens (Avian Farms, Nuland, Netherlands) were placed in conventional wire batteries and provided feed and water ad libitum.

Diets. For the first 20 days, control chickens were fed conventional starter ration that contained $1.04 \%$ calcium whilst ration containing $0.70 \%$ calcium was fed to the low group, and $1.36 \%$ calcium was fed to the high group. Grower rations were fed from 21 to 35 days with $0.89 \%$ calcium (controls), $0.59 \%$ calcium (low group), and $1.25 \%$ (high group). From Day 36, calcium content was adjusted to $0.80 \%, 0.49 \%$, and $1.14 \%$, respectively. Table 1 gives the composition of feed.

Antibody assay. Sera were assayed for haemagglutination inhibiting ant ibodies by micro assay (Beard, 1980).

Serum calcium. Calcium in serum samples was measured by atomic a bsorption in Perkin-Elmer absorption spectrophotometer Model 1100B (Analyt ical Methods for Atomic Spectrophotometry, 1982, Perkin-Elmer Co., Germany). Two tenths of a millilitre of serum was diluted to $10 \mathrm{ml}$ in $0.65 \%(\mathrm{w} / \mathrm{v}) \mathrm{LaCl}_{3} \times$ $\mathrm{H}_{2} \mathrm{O}$ diluent. Diluent was used for reagent blank. Samples were vaporised in airacetylene flame, and absorbency measured at $422.7 \mathrm{~nm}$.

Statistical analysis. Analysis was done with a JMP program (SAS, Inc., Cary, North Carolina). Observations of one-day-old chicks were excluded from the analysis. Effect of diet on serum calcium and antibody response was estimated by ANOVA. Groups were separated by Kruskal-Wallis tests. The influence of serum calcium as a covariant was estimated by analysis of covariance. Kruskal-Wallis tests were used to ascertain differences among groups within each time interval for body weight, serum calcium, and antibody titre. Regression analysis was used to measure dependence of antibody response on the level of serum calcium. Because $\mathrm{CV}$ for the antibody assay is larger than the other measurements, and in previous related studies by us significance was sometimes $0.05>p<0.10$, significance of antibody titres was considered at $\mathrm{p} \leq 0.10$. Statistical significance for other $\mathrm{pa}$ rameters was considered at $\mathrm{p} \leq 0.05$. 


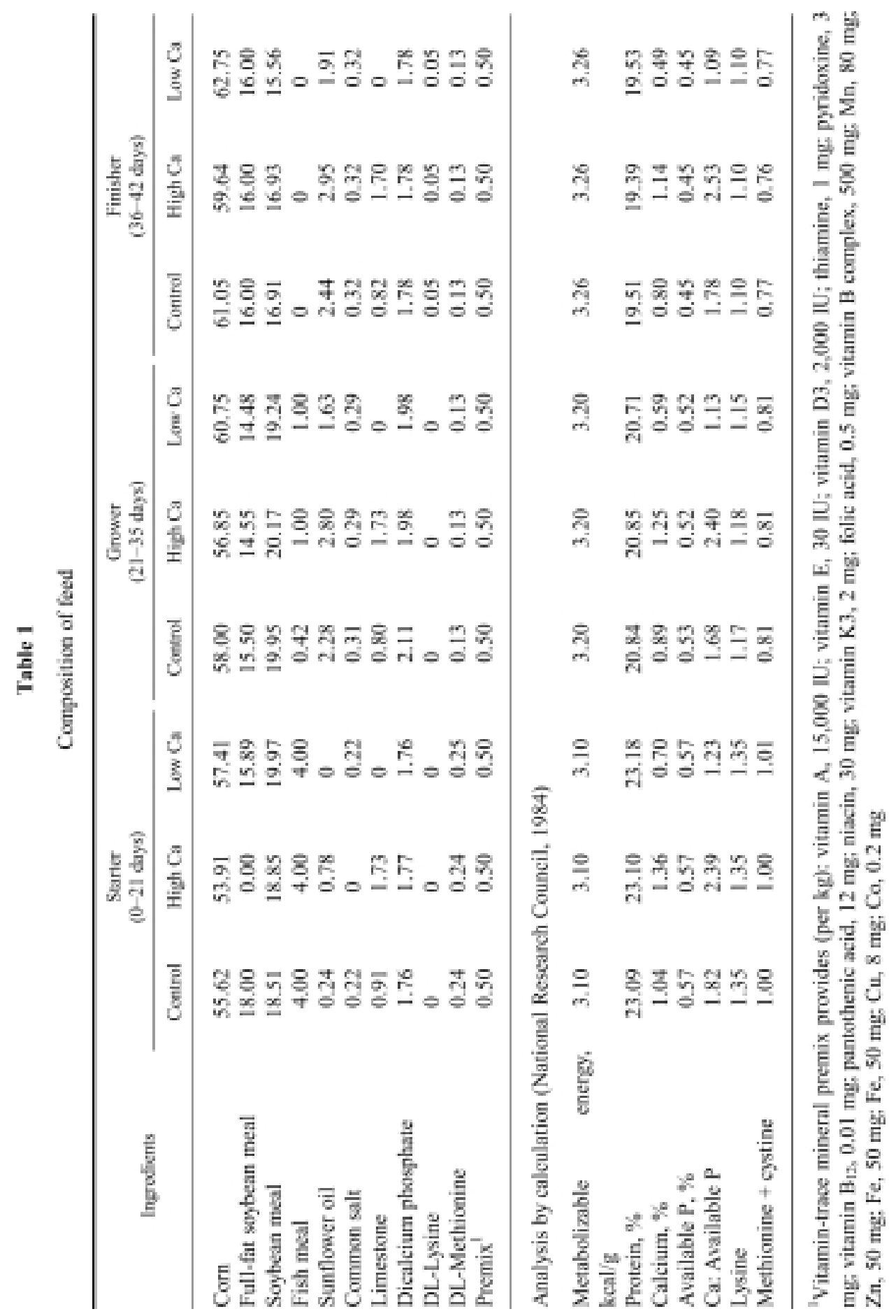




\section{Results and discussion}

Body weights were significantly depressed in chickens fed the low-calcium diet (Table 2). No signs of clinical disease or difference in behaviour were observed in any group.

Table 2

Mean body weights, weight gains, and feed conversion of chickens fed diets containing different levels of calcium

\begin{tabular}{|c|c|c|c|c|c|c|c|c|c|}
\hline \multirow{2}{*}{$\begin{array}{l}\text { Age } \\
\text { (days) }\end{array}$} & \multicolumn{3}{|c|}{ Control } & \multicolumn{3}{|c|}{ High calcium } & \multicolumn{3}{|c|}{ Low calcium } \\
\hline & $\begin{array}{l}\text { Weight } \\
\text { (g) }\end{array}$ & $\begin{array}{l}\text { Gain } \\
(\mathrm{g})\end{array}$ & $\begin{array}{l}\text { Conversion } \\
\text { g feed/ } \\
\text { g gain }\end{array}$ & $\begin{array}{l}\text { Weight } \\
(\mathrm{g})\end{array}$ & $\begin{array}{l}\text { Gain } \\
(\mathrm{g})\end{array}$ & $\begin{array}{l}\text { Conversion } \\
\text { g feed/ } \\
\text { g gain }\end{array}$ & $\begin{array}{l}\text { Weight } \\
\text { (g) }\end{array}$ & $\begin{array}{l}\text { Gain } \\
(\mathrm{g})\end{array}$ & $\begin{array}{l}\text { Conversion } \\
\text { g feed/ } \\
\text { g gain }\end{array}$ \\
\hline 01 & 38 & & & 37 & & & 34 & & \\
\hline 21 & $565^{\mathrm{a}}$ & 527 & 2.06 & $557^{\mathrm{a}}$ & 520 & 2.04 & $539^{\mathrm{a}}$ & 505 & 2.17 \\
\hline 35 & $1375^{\mathrm{a}}$ & 1337 & 2.04 & $1299^{b}$ & 1262 & 2.28 & $1270^{b}$ & 1236 & 2.33 \\
\hline 42 & $1768^{\mathrm{a}}$ & 1730 & 1.92 & $1729^{\mathrm{a}}$ & 1692 & 1.94 & $1655^{\mathrm{b}}$ & 1621 & 1.98 \\
\hline
\end{tabular}

Means within a row with different superscripts differ at $\mathrm{p} \leq 0.05$

The overall means for antibody titres were 2.5 for chickens fed the optimal diet, 3.2 for those fed the high-calcium diet, and 1.6 for those fed the low-calcium diet. Antibody titres of chickens fed the low-calcium diet were significantly less than titres of chickens fed the other diets $(p=0.024)$, while titres of chickens fed the highcalcium diet were different from those of chickens fed the optimal diet $(p=0.068)$. Overall, serum calcium levels were not different. Since serum calcium was a significant covariant, serum calcium (Table 3) and antibody titre (Table 4) were analysed at each time interval.

Table 3

Serum calcium levels $(\mathrm{mg} / \mathrm{L})$ in chickens fed diets containing different levels of calcium

\begin{tabular}{cccc}
\hline Age in days & Control & High calcium & Low calcium \\
\hline 01 & 75 & & \\
21 & $88^{\mathrm{a}}$ & $97^{\mathrm{b}}$ & $93^{\mathrm{c}}$ \\
35 & $80^{\mathrm{a}}$ & $79^{\mathrm{a}}$ & $76^{\mathrm{a}}$ \\
42 & $75^{\mathrm{a}}$ & $69^{\mathrm{a}}$ & $63^{\mathrm{b}}$ \\
\hline
\end{tabular}

Means within a row with different superscripts differ at $\mathrm{p} \leq 0.05$ 
Serum calcium levels and antibody titres were significantly different at 14 days when all groups were different, the high dietary calcium group being the highest, and the low group inexplicably higher than the control group (Table 3). We are unable to offer an explanation why serum calcium and antibody titres were higher in chickens fed low calcium diet than those fed the optimal diet. Antibody levels at 14 days were obviously lower than at hatch because of $\mathrm{d}$ ecline in maternal antibody (Table 4).

Table 4

Newcastle disease haemagglutination inhibition titres $\left(\log _{2}\right)$ in chickens fed diets containing different levels of calcium

\begin{tabular}{cccc}
\hline Age in days & Control & High calcium & Low calcium \\
\hline 01 & 3.3 & & \\
14 & $1.2^{\mathrm{a}}$ & $2.5^{\mathrm{b}}$ & $1.7^{\mathrm{c}}$ \\
28 & $4.3^{\mathrm{a}}$ & $3.5^{\mathrm{a}}$ & $3.6^{\mathrm{a}}$ \\
42 & $3.1^{\mathrm{a}}$ & $3.9^{\mathrm{b}}$ & $0.6^{\mathrm{c}}$ \\
\hline
\end{tabular}

Means within a row with different superscripts differ at $\mathrm{p} \leq 0.10$

Significant differences were not observed in serum calcium or active i mmune responses at Day 28. Antibody titres were significantly higher in the highcalcium group at Day 42. Serum calcium and antibody titres were significantly less in the low-calcium group at Day 42, in accord with our earlier work. Whereas Aslam et al. (1998) reported depressed cellular immunity in vitamin D deficient chickens that were hypocalcaemic, vitamin D might affect immunity by other means in addition to its effect on calcium metabolism. Antibody responses to SRBC were not affected. Whether calcium affects T-independent but not Tdependent responses remains to be determined. There seems little doubt that $\mathrm{h} y$ povitaminosis $\mathrm{D}$ and hypocalcaemia adversely affect cell-mediated immunity in several species, as mentioned in the introduction.

Analysis of covariance for the active immune response (Days 28 and 42) revealed a significant difference in antibody titre among the three groups $(\mathrm{p}=$ 0.013 ) but no effect of serum calcium or an interaction of serum calcium with diet. We refer to accepted the analysis of all the data that indicated an effect of serum calcium on antibody titre. Resolution of the issue will depend on further studies. Nevertheless, increased immune responses with high-calcium diets have been confirmed, and it may well be through serum calcium levels as they affect the intracellular cascade leading to activation of lymphocytes.

Since serum calcium was significant covariant for all the data and there is ample biochemical evidence for immune responsiveness being dependent on i n- 
tracellular events driven by calcium influx, it would be inappropriate to calculate correlation coefficients for serum calcium and antibody titre. The appropriate statistical measure for dependence of antibody on serum calcium is regression. Regression analysis revealed a strong dependence of antibody titre on serum ca 1cium $\left(r^{2}=0.98\right.$ at 14 days, 0.99 at 28 days, and 0.78 at 42 days). While the stimulatory effect of high dietary calcium on antibody titre has been confirmed, the strong association of antibody responses with serum calcium levels further reinforces the importance of calcium in immunity.

Whereas calcium deficiency adversely affects immunity, increased ca 1cium enhances immunity in chickens (Ragland et al., 1994; Bakalli et al., 1996; the present study), in rats (Sukhanov et al., 1995), and in man (Halpern et al., 1991; Koval, 1997). The effects of minerals in feed, especially calcium, on i mmune responses need to be better defined, and molecular explanations eluc idated. Study of dietary calcium and immunity has been mostly ignored, and no molecular correlates have been identified for dietary calcium. Involvement of calcium in molecular signalling in immunity is well known, however ( Cardenas and Heitman, 1995), and it is plausible that dietary calcium may drive these mechanisms. Calcium induces transcription of mRNA for interferon-gamma through activation of protein kinase $\mathrm{C}$ or cAMP (Kaldy and Schmitt-Verhulst, 1995). Intracellular calcium also stabilizes the amplified mRNA, demonstrating its involvement in post-transcriptional events as well. Calcineurin, a calciumbinding protein, has been shown to be rate-limiting for human lymphocyte act ivation, including amplification of mRNA for interferon-gamma (Batiuk et al., 1997), but it is not known if intracellular calcineurin is affected by treatments that enhance calcium influx. Apparently, dietary calcium can drive these pro cesses. Takahashi and Yamaguchi (1995) reported that orally administered ca 1cium increased activity of $\left(\mathrm{Ca}^{2+}-\mathrm{Mg}^{2+}\right)$-ATPase in hepatic plasma membranes of rats, and it is reasonable to assume that calcium channels in lymphocytes also would be activated. In suggesting these molecular events may explain enhanc ement of immunity by dietary calcium, we draw attention to increased interferongamma in lymphocytes from young adults consuming large amounts of yoghurt that is high in calcium content (Halpern et al., 1991).

\section{Acknowledgement}

We thank Prof. Dr. Remzi Bakalli, University of Georgia, for critical review of the manuscript and helpful comments. 


\section{References}

Aslam, S. M., Garlich, L. D. and Qureshi, M. A. (1998): Vitamin D deficiency alters the immune responses of broiler chicks. Poultry Sci. 77, 842-849.

Bakalli, R. I., Ragland, W. L. and Novak, R. (1996): Growth and immune responses of chickens fed various dietary concentrations of calcium and phosphorus. Krmiva 38, 149-157.

Batiuk, T. D., Kung, L. and Halloran, P. F. (1997): Evidence that calcineurin is rate-limiting for primary human lymphocyte activation. J. Clin. Invest. 100, 1894-1901.

Beard, C. W. (1980): Serologic procedures. In: Hitchner, S. B., Domeruth, S. H., Purchase, H. G. and Williams, J. E. (eds) Isolation and Identification of Avian Pathogens. American Association of Avian Pathologists, Kennett Square, Pennsylvania, pp. 129-135.

Birkett, N. J. (1998): Comments on a meta-analysis of the relation between dietary calcium intake and blood pressure. Am. J. Epidemiol. 148, 223-228.

Cardenas, M. E. and Heitman, J. (1995): Role of calcium in T-lymphocyte activation. Advances in Second Messenger Phosphorylation Research 30, 281-298.

Garlich, J. D., Qureshi, M. A., Ferket, P. R. and Aslam, S. M. (1992): Immune system modulation by dietary calcium. In: Proceedings of the $19^{\text {th }}$ World Poultry Congress, Vol. 1. Amsterdam, The Netherlands, pp. 618-619.

Halpern, G. M., Vruwink, K. G., van de Water, L., Keen, C. L. and Gershwin, M. E. (1991): Influence of long-term yogurt consumption in young adults. Int. J. Immunother. 7, 205-210.

Johnsson, C., Binderup, L. and Tufveson, G. (1996): Immunosuppression with the vitamin D analogue MC 1288 in experimental transplantation. Transplant. Proc. 28, 888-891.

Kaldy, P. and Schmitt-Verhulst, A.-M. (1995): Regulation of interferon-gamma mRNA in a cytolytic $\mathrm{T}$ cell clone: Ca 2+-induced transcription followed by mRNA stabilization through activation of protein kinase C or increase in cAMP. Eur. J. Immunol. 25, 889-895.

Koval, E. A. (1997): The relationship between immune status characteristics and the trace element level in men with ischaemic heart disease (in Russian). Likarska Sprava, Number 5, pp. 59-63.

McCarron, D. A. (1998): Importance of dietary calcium in hypertension [Letter]. J. Am. Coll. Nutr. 17, 97-98.

Ragland, W. L., Bakalli, R. I., Pesti, G. M., Mazija, H., Domi, X., Novak, R. and Konjufca, V. H. (1994): Immune modulation of chickens by dietary calcium and lead. Krmiva 36, 19-23.

Sukhanov, B. P., Gorshkov, A. I., Korolev, A. A., Vorob'ev, A. A., Neviskii, Yu. V., Vislobokov, A. V., Poliakov, Yu. A. and Inozemtseva, L. O. (1995): Effects of food rations with different levels of calcium on parameters of cellular immunity of sensitized rats (in Russian). Gigiena i Sanitaria, Number 3, pp. 22-23.

Takahashi, H. and Yamaguchi, M. (1995): Increase of $\left(\mathrm{Ca}^{2+} / \mathrm{Mg}^{2+}\right)$-ATPase in hepatic plasma membranes of rats administered orally calcium: The endogenous role of regucalcin. Mol. Cell. Biochem. 144, 1-6.

Yang, S., Smith, C., Prahl, J. M., Luo, X. and DeLuka, H. F. (1993): Vitamin D deficiency suppresses cell-mediated immunity in vivo. Arch. Biochem. Biophys. 303, 98-106. 